九州大学学術情報リポジトリ

Kyushu University Institutional Repository

\title{
Indonesia Recent Research of Bioethanol for Internal Combustion Engine
}

Yamin, Iqbal

Departement of Mechanical Engineering, Universitas Indonesia

Sugiarto, Bambang

Departement of Mechanical Engineering, Universitas Indonesia

Abikusna, Setia

Departement of Mechanical Engineering, Universitas Indonesia

https://doi.org/10.5109/4742131

出版情報 : Evergreen. 8 (4)，pp.850-854，2021-12. 九州大学グリーンテクノロジー研究教育センター バージョン:

権利関係 : 


\title{
Indonesia Recent Research of Bioethanol for Internal Combustion Engine
}

\author{
Iqbal Yamin $^{1}$, Bambang Sugiarto, ${ }^{1, *}$, Setia Abikusna ${ }^{1}$ \\ ${ }^{1}$ Departement of Mechanical Engineering, Universitas Indonesia, Postal 16424, Indonesia \\ *Corresponding Author’s email: bangsugi@eng.ui.ac.id
}

(Received April 30, 2021; Revised December 16, 2021; accepted December 16, 2021).

\begin{abstract}
The limitation of fossil energy resources and the increasing need for fossil fuels encourage the development of renewable energy resources. An alternative energy currently being developed such as biomass utilized as an alternative fuel in motorized vehicles are bioethanol. This Paper discusses the development of research on the utilization of bioethanol in Indonesia, starting from low-grade ethanol distillation into high grade up until the utilization of additives in a mixture of bioethanol and gasoline on internal combustion engine. Bioethanol fuel mainly produced by sugar fermentation process from biomass, it can also be manufactured by chemical process. Today the use of bioethanol in Indonesia as fuel still very low, however the production of low-grade bioethanol often found as a type of beverage consumed by certain communities, both traditional and industrial scale. In Indonesia, bioethanol mixture to be a fuel is usually anhydrous ethanol with a concentration of $>99.5 \%$. If fully used as fuel it is necessary to modify the engine, but if it is mixed with the gasoline then the engine modification is not required. The addition of bioethanol to gasoline will certainly change the fuel properties, the fuel will be more difficult to self-ignite so the pressure generated in the combustion chamber will be more consistent.
\end{abstract}

Keywords: Alternative energy, Bioethanol, Gasoline, Internal combustion engine

\section{Introduction and background}

Indonesia is still dependent on non-renewable energy sources, this condition is seen from the growth of motor vehicles over the past five years has reached $8.63 \%$ per year ${ }^{1)}$. Along with the increasing number of vehicles, the amount of fuel consumption has also increased ${ }^{2}$. One alternative energy currently being developed as an alternative fuel in motorized vehicles is bioethanol ${ }^{3}$.

Today the utilization of bioethanol in Indonesia as fuel is very $l o w^{4}$. In Indonesia the production of bioethanol often found as a type of beverage consumed by certain communities, both traditional and industrial scale ${ }^{5}$. There are certain conditions for bioethanol so it can be used as a mixture in fuel, one of them are the concentration of ethanol has to be greater than $99.5 \%{ }^{6,7}$. This kind of ethanol known as anhydrous ethanol.

Anhydrous ethanol is used because the water content is very small, and can even be said to be pure so that when mixed directly with gasoline, a homogenous mixture will be obtained ${ }^{8)}$. While hydrous ethanol has a lower ethanol concentration and more water content in it so it can't be directly mixed with gasoline ${ }^{9)}$. Therefore, we need a simple technology that can accommodate low-grade bioethanol produced by the community to be transformed into high-grade bio-ethanol ${ }^{10)}$, and the results can be directly applied as mixed fuel on the engine ${ }^{11,12)}$.
Engine modification are necessary if bioethanol used as a fuel, but if its mixed with gasoline then the engine modification is not required ${ }^{13,14)}$. Bioethanol addition to gasoline will certainly change its properties ${ }^{15,16)}$, the fuel will be more difficult to self-ignite ${ }^{17,18)}$ and the pressure generated in the combustion chamber will be more consistent ${ }^{19,20)}$. This Paper discusses the development of research about utilization of bioethanol in Indonesia, starting from low-grade ethanol distillation to high grade ethanol ${ }^{21)}$ up until the utilization of additives in a mixture of bioethanol and gasoline on internal combustion engine $^{22)}$.

\section{Method and experimental setup}

The study began in 2010 with the design of compact distillatory as ethanol distillation devices. Compact distillatory consists of three main parts, namely evaporator, separator and condenser.

Fig. 1 shows that the evaporator section is mounted on the exhaust manifold with the objective of utilizing the heat from the exhaust gases for heating the distillation and the installation is placed in a chamber inside the dynamic fuel engine without changing the physical appearance conditions of the motor so that it is possible to carry out the test under actual conditions. Furthermore, testing of the distillation rate and ethanol concentration are 
conducted.

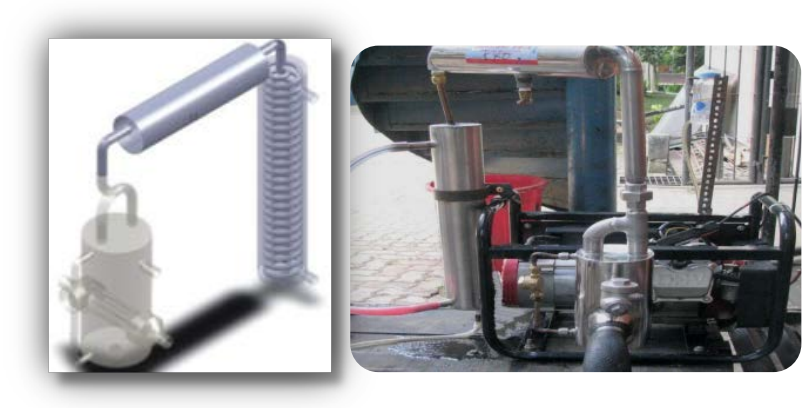

Fig. 1: Compact Distillatory

In 2011 a study was conducted on the effect of load variations on the distillation rate and ethanol concentration. Furthermore, an analysis of motor performance was also carried out to determine fuel consumption and exhaust emissions from the combustion chamber. This research was conducted on a static motor, Genset Sumura 1500cc, as shown in Fig. 2.

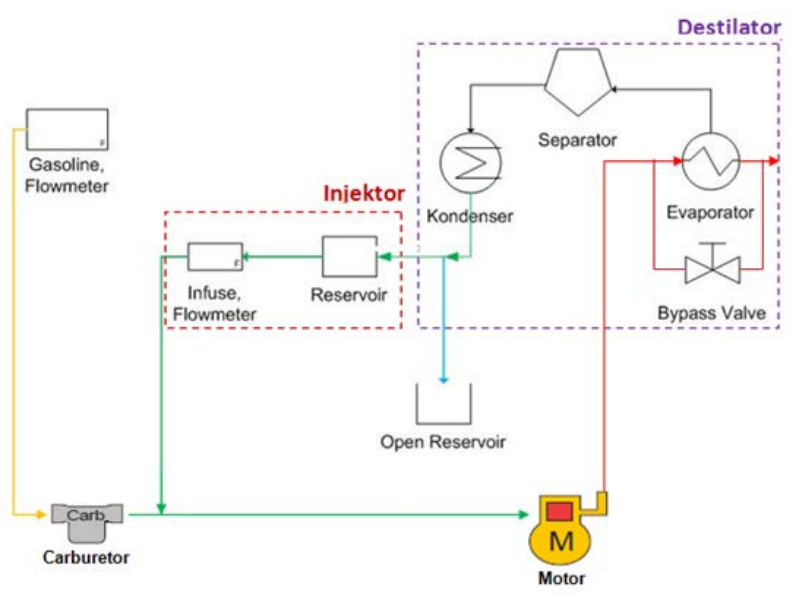

Fig. 2: flow chart compact distillatory on a static motor

Further research on bioethanol in 2012 was carried out on dynamic motor engines (125cc Suzuki Thunder Motor). It can be seen from Fig. 3 that the management of ethanol fuel is done through main jets and pilot jets. Then the

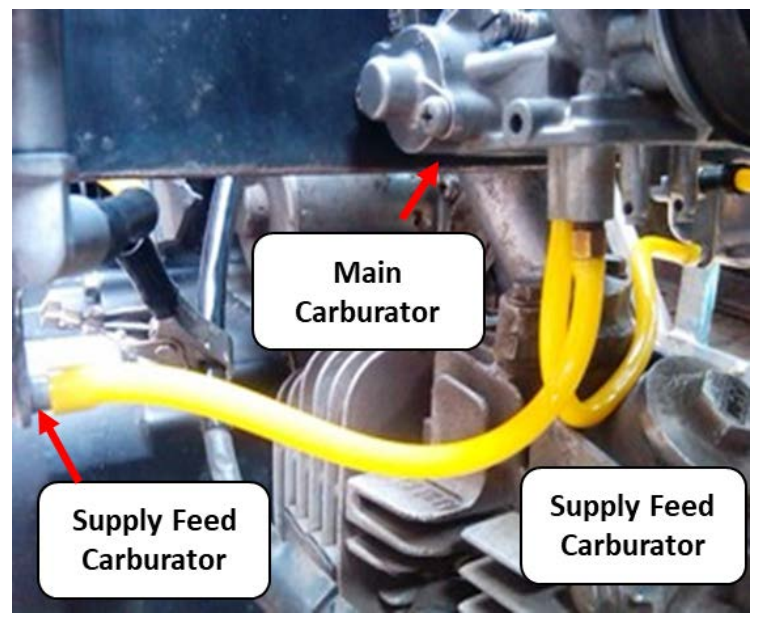

Fig. 3: Fuel supply system on dynamic motor compact distillatory test is also performed with variations in the load on the distillation rate and ethanol concentration in the dynamic motor. The performance of the motor is analyzed to see its effect.

In 2013 a CFD simulation was carried out to analyze the combustion characteristics that occur in a mixture of gasoline with bioethanol. In addition, the development of a compact distillatory is also done by adding a gate valve to the bypass channel to control the temperature of the flue gas that will be used for the distillation process as can be seen on Fig. 4.

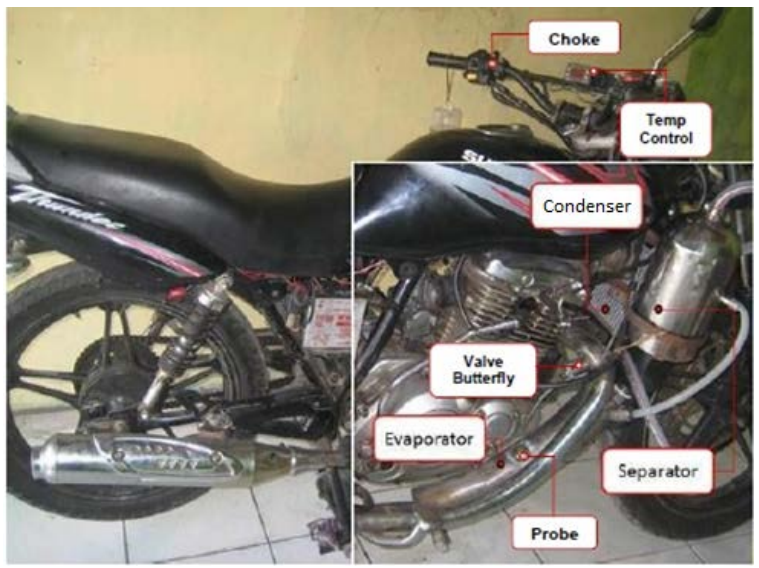

Fig. 4: Control Temperature on Compact Distillatory

In 2014 the research was continued by optimizing the compact distillatory in the separator section ${ }^{23)}$. In 2016, bioethanol research was continued by conducting performance and emission testing in accordance with SNI and design of bioethanol hydrous fuel mixer ${ }^{24)}$.

In 2017 bioethanol research was carried out with a 150cc Spark Ignition (SI) Honda Matic motor. Analyzes engine performance and emissions with bioethanol gasoline blend. Addition of oxygenated cycloheptanol additive to compare performance and emissions using fuel mixture E0, E5, E10, E15 plus oxygenated additives for every bioethanol gasoline blend.

In 2018 The study continued with few changes to the test engine. The test engine used is a $125 \mathrm{cc}$ SI engine on a semi-automatic motor that utilize dyno engine as a measuring tool in this test method. Tests were also carried out using oxygenated cyclohexanol additives.

In 2019 the study continued to analyze the heat release rate in the combustion chamber using pressure transducer $^{25)}$. The test was done with fuel mixture E0, E5, E10 and E15 plus the additions of oxygenated additives.

\section{Results and Discussion}

To produce high grade bioethanol as a gasoline fuel mixture, research has been carried out on the design of compact distillatory by utilizing the exhaust heat of motorbikes since 2010. At first the performance of the compact distillatory has not shown satisfactory distillation results with the highest ethanol concentration $81.7 \%$ 
reached on engine speed $1800 \mathrm{rpm}$. The level of bioethanol produced can be seen in Fig. 5 .

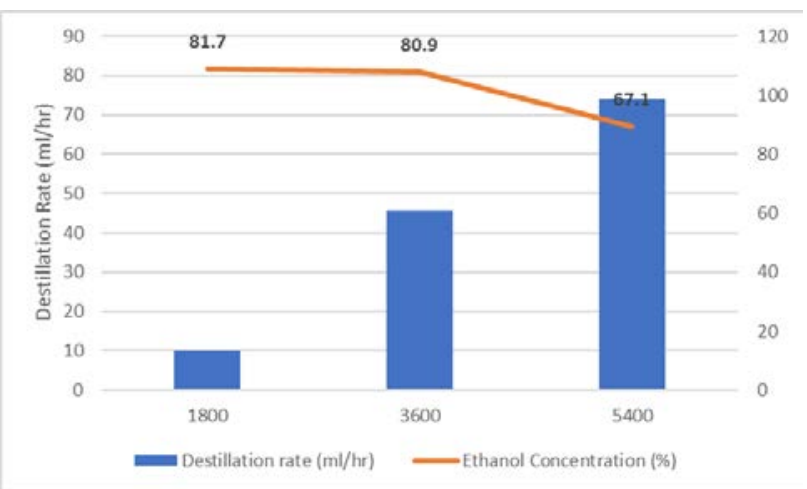

Fig. 5: Compact distillatory performance

Subsequently, a redesign and optimization of the compact distillatory is done by changing the separator component into a type of batch-sieve tray distillation column which is expected to produce high-grade bioethanol and increase the distillation rate. The goal to redesign the compact distillatory is to produce a $95 \%$ bioethanol concentration. The new dimension of separator components; 1.5-inch diameter, $900 \mathrm{~mm}$ height, tray number 8, tray hole diameter $1 \mathrm{~mm}$ and 128 holes per tray.as seen in Fig. 6.

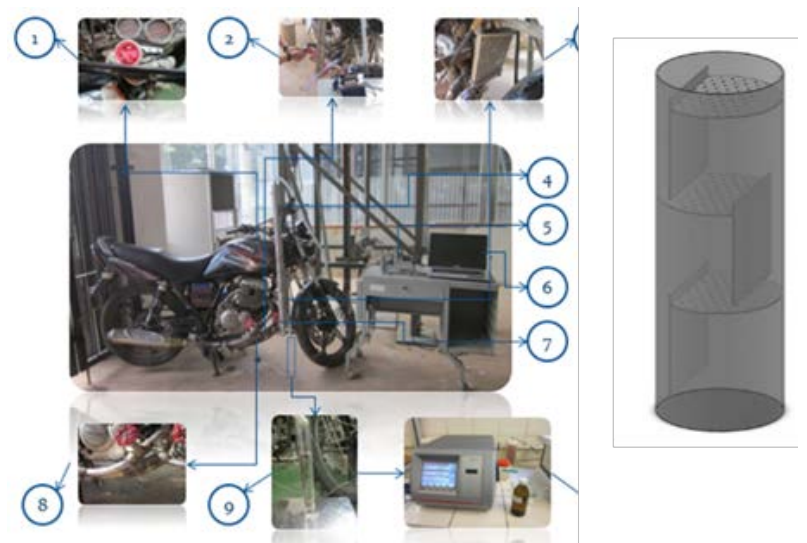

Fig. 6: Optimization Compact Distillatory

The test with different distance between tray experimented and the result can be seen in Fig. 7. In engine speed $3600 \mathrm{rpm}$ with tray distance $100 \mathrm{~mm}$ produce the highest ethanol with concentration $93.36 \%$.

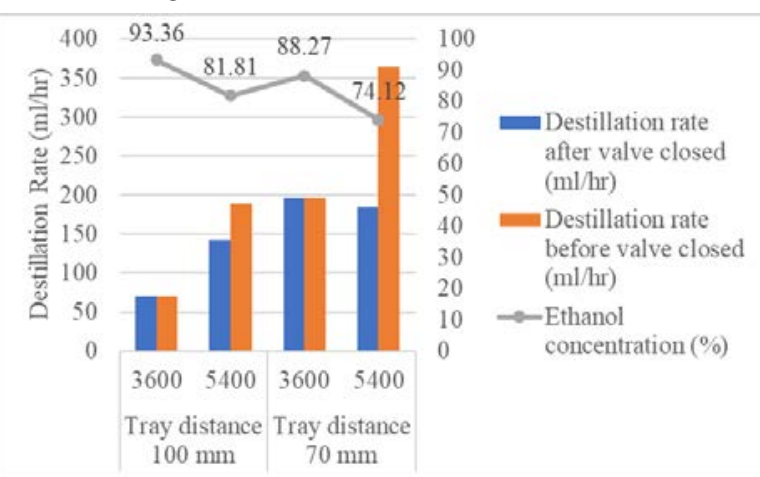

Fig. 7: Optimization Compact Distillatory Performance
Further tests are carried out to determine engine performance and exhaust emissions from the addition of bioethanol as a mixing fuel with variations in the addition of $10 \%$ and $20 \%$. It can be seen from Fig. 8 that as ethanol concentration increase, power, torque and fuel consumption increases too.
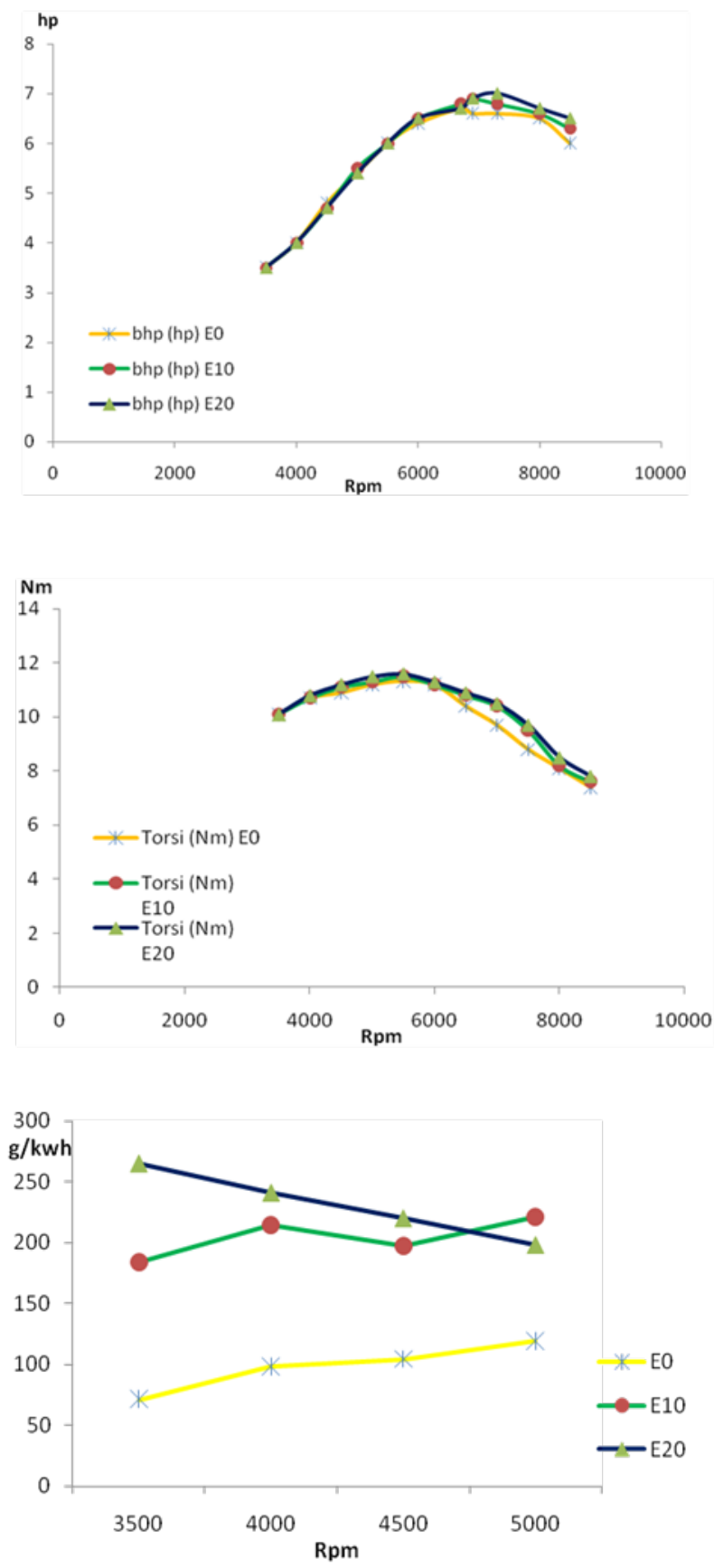

Fig. 8: Ethanol - Gasoline Blend Engine Performance

Another test is conducted to analyze the heat release rate of ethanol gasoline blend with the addition of oxygenated additives. The pressure generated in the combustion chamber obtained using pressure transducer. It can be seen from Fig. 9 that 5\% ethanol gasoline blend with oxygenated additives increases heat release rate, especially on lower engine speed. 

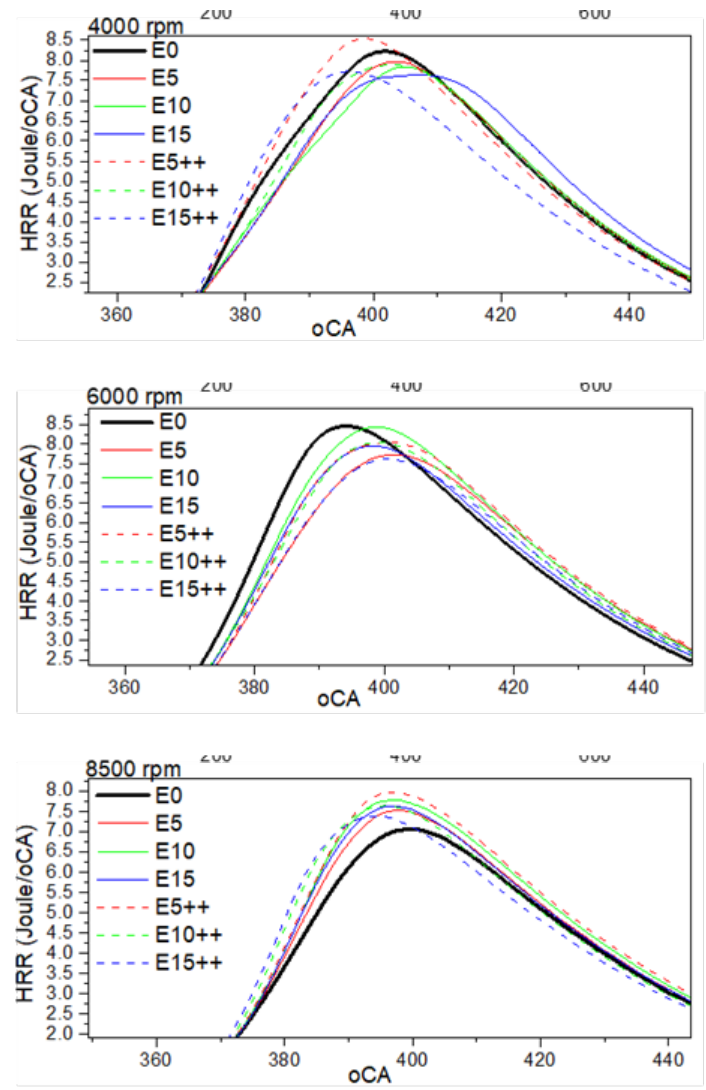

Fig. 9: Heat Release Rate of Rate Ethanol - Gasoline

\section{Conclusion}

The following conclusion can be made from this study, to produce high grade bioethanol research has been carried out on the design of compact distillatory by utilizing the exhaust heat of motorbikes. At first the performance of the compact distillatory has not shown satisfactory distillation results with the highest ethanol concentration $81.7 \%$ on engine speed $1800 \mathrm{rpm}$. Subsequently, a redesign and optimization of the compact distillatory is done by changing the separator component into a type of batch-sieve tray distillation column. The new dimension of separator components; 1.5-inch diameter, $900 \mathrm{~mm}$ height, tray number 8 , tray hole diameter $1 \mathrm{~mm}$ and 128 holes per tray. Further tests are carried out to determine engine performance and exhaust emissions from the addition of bioethanol as a mixing fuel with variations in the addition of $10 \%$ and $20 \%$. It can be seen from Fig.7 that as ethanol concentration increase the power increases, torque also increases, and the fuel consumption increases too. Next test is experimented to analyze the heat release rate of ethanol gasoline blend with the addition of oxygenated additives. It can be seen from that $5 \%$ ethanol gasoline blend with oxygenated additives increases heat release rate, especially on lower engine speed. Further test needs to be done to analyze the effect of the Carbon cycle length towards engine performance.

\section{Acknowledgements}

The authors would like to thank PITTA UI for providing the grant in this research so that it can be completed well.

\section{References}

1) B.P. Statistik, "Badan pusat statistik," Badan Pus. Stat., (2017).

2) Kementrian ESDM, A. Wahyu Kencono, M. Dwinugroho, E. Satra Baruna, and N. Ajiwihanto, "Handbook of energy \& economic statistics of indonesia 2015,” 73 (2015).

3) R. Suryaningsih, "Bioenergy plants in indonesia: sorghum for producing bioethanol as an alternative energy substitute of fossil fuels," Energy Procedia, 47 211-216 (2014).

4) T.W. Widodo, and E. Rahmarestia, "Current status of bioenergy development in Indonesia,” in: Proc. Reg. Forum Bioenergy Sect. Dev. Challenges, Oppor. W. Forward. Bangkok, 2008.

5) D. Khatiwada, and S. Silveira, "Scenarios for bioethanol production in indonesia: how can we meet mandatory blending targets?,” Energy, 119 351-361 (2017).

6) B.M. Masum, M.A. Kalam, H.H. Masjuki, S.M.A. Rahman, and E.E. Daggig, "Impact of denatured anhydrous ethanol-gasoline fuel blends on a sparkignition engine," Rsc Adv., 4 (93) 51220-51227 (2014).

7) Z.F. Zahara, "Economic assessment of the sugarcanebased bio-refinery in indonesia,” Evergreen, 5 (2) 6777 (2018).

8) S. Kumar, N. Singh, and R. Prasad, "Anhydrous ethanol: a renewable source of energy,” Renew. Sustain. Energy Rev., 14 (7) 1830-1844 (2010).

9) S. Abikusna, B. Sugiarto, and R. Monasari, "Utilization distillate low grade bioethanol as fuel mixing on SI engine (from carburetor to injection)," in: AIP Conf. Proc., 2018: p. 40004. doi:10.1063/1.5049987.

10) Y.H. Lee, C.H. Chen, M.A.U. Fazara, and M.D.M.I. Hatim, "Production of fuel grade anhydrous ethanol: a review,” in: IOP Conf. Ser. Earth Environ. Sci., IOP Publishing, 2021: p. 12016.

11) S. Abikusna, B. Sugiarto, and A. Zulfan, "Fuel consumption and emission on fuel mixer low-grade bioethanol fuelled motorcycle," MATEC Web Conf., 101 (2017).

12) W. Sumaryono, “Technology development in bioethanol production in indonesia,” in: Asian Sci. Technol. Semin., 2007.

13) S. Sakai, and D. Rothamer, "Impact of ethanol blending on particulate emissions from a sparkignition direct-injection engine,” Fuel, 236 15481558 (2019).

14) B. Sugiarto, Maymuchar, C.S. Wibowo, F. Adian, R. Hargiyanto, H. Krisnanto, and D. Dwika, 
"Optimizing four stroke engine performance with ignition time modification on gasoline-Bioethanol blends,” in: AIP Conf. Proc., AIP Publishing LLC, 2020: p. 30044.

15) S.A. Shirazi, B. Abdollahipoor, J. Martinson, K.F. Reardon, and B.C. Windom, "Physiochemical property characterization of hydrous and anhydrous ethanol blended gasoline,” Ind. Eng. Chem. Res., 57 (32) 11239-11245 (2018).

16) S.K. Thangavelu, A.S. Ahmed, and F.N. Ani, "Review on bioethanol as alternative fuel for spark ignition engines,” Renew. Sustain. Energy Rev., 56 820-835 (2016).

17) J.P. Szybist, and D.A. Splitter, "Pressure and temperature effects on fuels with varying octane sensitivity at high load in si engines," Combust. Flame, $177 \quad 49-66 \quad$ (2017). doi:10.1016/j.combustflame.2016.12.002.

18) M. Owczuk, A. Matuszewska, M. Odziemkowska, M. Bednarski, M.K. Wojs, and J. Lasocki, "Evaluation of the impact of the hydration degree of bioethanol on the operation parameters of the spark-ignition engine," Combust. Engines, 56 (2017).

19) I. Yamin, B. Sugiarto, M.T. Suryantoro, S. Abikusna, and S.F. Maulidina, "Analysis of utilization of low grade bioethanol and oxygenated additives to COV and heat release rate on SI engine," in: AIP Conf. Proc., AIP Publishing LLC, 2020: p. 30030.

20) K. Morganti, M. Almansour, A. Khan, G. Kalghatgi, and S. Przesmitzki, "Leveraging the benefits of ethanol in advanced engine-fuel systems," Energy Convers. Manag., 157 480-497 (2018).

21) S. Abikusna, B. Sugiarto, D. Suntoro, and Azami, "Low grade bioethanol for fuel mixing on gasoline engine using distillation process,” in: AIP Conf. Proc., 2017: p. 20019.

22) A. Setia, S. Bambang, M. Ratna, and Y. Iqbal, "The effect of additive on combustion characteristics and cycle to cycle variations on si engine fueled by gasoline and bioethanol,” Восточно-Европейский Журнал Передовых Технологий, (6 (6)) 27-36 (2018).

23) I. Yamin, B. Sugiarto, S. Abikusna, and D. Suntoro, "The use of low grade bio ethanol as fuel mixer in gasoline engine with optimization compact distillator," in: E3S Web Conf., 2018: p. 2004. doi:10.1051/e3sconf/20186702004.

24) S. Abikusna, B. Sugiarto, R. Monasari, R. Aditya, and D. Hendrawan, "Performance analysis (WHP and torque) on SI engine fueled with low-grade bioethanol and oxygenated fuel additive," in: IOP Conf. Ser. Earth Environ. Sci., IOP Publishing, 2018: p. 12058. doi:10.1088/1755-1315/105/1/012057.

25) S. Abikusna, B. Sugiarto, and I. Yamin, "Utilization analysis of bioethanol (low grade) and oxygenated additive to cov and gas emissions on si engine," Evergreen, 7 (1) 43-50 (2020). 